\title{
Church and Clergy, and the Religious Life of Toronto's Italian Immigrants, 1900-1940
}

\section{John Zucchi}

Volume 50, numéro 2, 1983

Bilan de l'histoire religieuse au Canada

Canadian Catholic History: A survey

URI : https://id.erudit.org/iderudit/1007221ar

DOI : https://doi.org/10.7202/1007221ar

Aller au sommaire du numéro

Éditeur(s)

Les Éditions Historia Ecclesiæ Catholicæ Canadensis Inc.

ISSN

0318-6172 (imprimé)

1927-7067 (numérique)

Découvrir la revue

Citer cet article

Zucchi, J. (1983). Church and Clergy, and the Religious Life of Toronto's Italian Immigrants, 1900-1940. Sessions d'étude - Société canadienne d'histoire de

l'Église catholique, 50(2), 533-548. https://doi.org/10.7202/1007221ar

Tous droits réservés @ Les Éditions Historia Ecclesiæ Catholicæ Canadensis Inc., 1983
Ce document est protégé par la loi sur le droit d'auteur. L'utilisation des services d'Érudit (y compris la reproduction) est assujettie à sa politique d'utilisation que vous pouvez consulter en ligne.

https://apropos.erudit.org/fr/usagers/politique-dutilisation/ 


\title{
Church and Clergy, and the Religious Life of Toronto's Italian Immigrants, 1900-1940
}

\author{
by John ZucchI \\ University of Toronto
}

The study of the religious history of ethnic communities is only beginning to emerge in Canada. In the United States the work of Timothy L. Smith, Silvano Tomasi, Rudolph J. Vecoli, and others has found strong correlations between the religious life of the immigrants and their ethnic identity and community politics. ${ }^{1}$ This paper, which studies the administration of Italian national parishes, the Italian clergy, and the religious life of Toronto's pre-war Italian immigrants, does not pretend to establish new theories on the subject of immigrant religious life. Rather it proposes a general structure for studying the significant problems in Toronto's Italian community in particular, and the North American urban ethnic community in general. A study of the religious live of the immigrant cannot be separated from an examination of the views of the clergy and the Church hierarchy regarding immigrants, and the activities of national parishes. The dialectic between these three sectors had a marked influence on the texture of religious life among Toronto's Italian immigrants. This paper, then, examines a number of issues under the heading of "religious life." Because the church hierarchy and clergy were instrumental in developing and guiding the national parishes, their disposition to and assumptions about the

\footnotetext{
${ }^{1}$ Smith, "Religion and Ethnicity in America," 55-1 185. Rudolph J. Vecoli, "Prelates and Peasants: Italian Immigrants and the Catholic Church," Journal of Social History 2 (Spring 1969), 217-68; and "Cult and Occult in Italian American Culture," Immigrants and Religion in Urban America, ed. by Randall M. Millerand Thomas D. Marzik, Philadelphia: Temple University Press, 1977, pp. 25-47. Silvano M. Tomasi, Piety and Power: The Role of the Italian Parishes in the New York Metropolitan Area, 1880-1930, New York: Center for Migration Studies, 1975.

Abbreviations. AAT: Archdiocesan Archives of Toronto; UCA: United Church Archives; ABPR: Archives of the Brooklyn Province of the Redemptorists; AFPIC: Archives of the Franciscan Province of the Immaculate Conception (New York).
} 
immigrants must be analyzed. The most important of these was an assumption on the part of bishops, priests, and religious orders that the migrants from many villages in the southern European peninsula were Italians and shared a common national identity. For the bishops, of Irish or Highland Scot background, who had previously worked in the United States, such a perspective coincided with their pragmatic, progressive approach to problem-solving, which called for, above all, efficiency and expediency. It was more practical to approach the immigrants with the assumption that they spoke one language and belonged to one cult. Italian priests and religious orders serving in Toronto could not but view their parishioners as Italian nationals; especially during the fascist era, they approached their fold with the understanding that they, the clerics, were Catholic missionaries civilizing an underdeveloped people.

The clergy's often condescending attitudes were not accepted unquestioningly by the immigrants, as an examination of the laity's response to the priests reveals. The final part of this paper is concerned with the participation of the immigrants in the national parish system. The experience of forming or joining an ethnic parish made immigrants more aware of their Italian national background and of the patria (the home country). However, as we shall see, the immigrants continued to practice traditional forms of spiritual worship imported from their hometowns, and some townsgroups were able to carve their own niche in Toronto's national parish structure.

From its earliest "mission work" among Toronto's Italians, the Archdiocese faced the difficult problem of how to deal effectively with this immigrant group centred in the Ward, Toronto's downtown immigrant quarter, but also dispersed throughout the city. By 1902, when Rev. Cyril Dodsworth of St. Patrick's Church, an Irish parish, began to celebrate Mass for about 70 Italian families in his parish, the Italian population had been established in the College and Grace Streets area, along Queen Street, and around Dufferin Street and Davenport Avenue for a long time. In December 1906, Dodsworth hurt himself in a fall and was unable to continue his work among the Italians. ${ }^{2}$ It was not until the apostolic delegate, Monsignor Sbarretti, pressured Archbishop Lynch's successor, Fergus McEvay, that the archidiocese found a replacement for Father Dodsworth.

\footnotetext{
2 John F. Byrne, Redemptorist Centenaries 1832-1932, Philadelphia: The Dolphin Press, 1932, p. 374.
} 
The first issue was to determine whether or not a national parish for Italians was necessary and viable. Archbishop McEvay asked his secretary to take a census of all Italians in the city and when the census was completed, McEvay determined that a national parish was indeed viable. The clergy, he indicated, would be "less priests than missionaries:"

men of zeal who will visit the homes of these people not merely in your parish but also in the adjoining parishes for... the boundaries for the Italians can be extended to any reasonable distance from St. Patrick's parish.

In November, 1908 the Irish relinquished St. Patrick's to the Italians and the Church was renamed Our Lady of Mount Carmel. ${ }^{3}$

The diffuse nature of Italian settlement in the city became a persistent source of anxiety for the clergy and the hierarchy. The absence of tenements in Toronto resulted in a low density of immigrants from a particular ethnic group in a given block. In 1913 the Archbishop transferred St. Agnes Church on Dundas and Grace Streets, in the second Little Italy, from the Irish to the Italians, and he chose Spadina Avenue as the boundary for the two Italian parishes. ${ }^{4}$ St. Clement's Church was partially constructed in 1915 at Dufferin Street and Davenport Avenue. Masses were celebrated in the basement until the structure was completed in 1934 and renamed St. Mary of the Angels. Italians north of Bloor Street and west of Spadina Avenue were under the jurisdiction of that parish. However, as late as 1922, the pastor of St. Agnes, still confused about his jurisdiction, inquired about those Italians whose homes were "extra limites parociae of St. Agnes, but extra limites of any other Italian parish."

The national parish structure in Toronto had been established in 1908 with the help of an immigration specialist from Italy, Father Pietro Pisani, who journeyed to the city on the recommendation of the apostolic delegate. The attitude shared by the local church hierarchy, religious orders, and clerics was that the shortcomings of a national parish among a dispersed ethnic group could be countered by missionary zeal. The approach of all three of these groups towards the city's Italians was one of colonizers helping an almost uncivilized people.

\footnotetext{
${ }^{3}$ McEvay to Brick (rector of St. Patrick's Church), 3 Aug. 1908, McEvay Papers, AAT.

${ }^{4}$ Lawrence Jung Papers, Archives of the Baltimore Province of the Redemptorists, Brooklyn, N.Y. (ABPR).
} 
In the search for a priest for Toronto's Italian immigrants, Archbishop McEvay requested of the Redemptorists that two clerics who knew "both English and Italian $\mid$ be $\mid$ set apart to save their people." 5 In his response to the archbishop, the provincial of the Redemptorists in Baltimore, relayed what he took for common knowledge:

While we know that the spiritual betterment of these Southern Italians is an almost impossible task, partly on account of the inborn indifference of this people: still we would gladly do all in our power to second your efforts if satisfactory arrangements could be made. ${ }^{6}$

The diocesan clergy - especially Fr. Aloysius Scafuro and Joseph Longo, who between them ran St. Clement's for almost twenty years were just as capable of this condescending attitude. They were convinced that their calling among the city's Italians was missionary work among a suspect people. Some of the priests also believed that only calculated moves would keep their parishioners in check. In 1920, Aloysius Scafuro pastor at St. Clement's wrote Archbishop NcNeil

The little experience that I got from missions in different parts of America has taught me that the Italians, in the beginning, submit the poor priest to a cruel and shameful examination. No priest can work without a little prestige. The sinners and the open and concealed enemies of the church not been $[$ sic $]$ able to find faults in my life... are continually setting traps for me... If they succeed to trample the priest under their feet, the mission would be ruined. ${ }^{7}$

Despite his warning to the Archbishop that these cunning parishioners must be scrutinized, Scafuro added that "Some questions brought up are above the average intelligence of the working people of my parish." Ten days earlier he had advised $\mathbf{M}^{\mathrm{gr}}$ Treacy, pastor of nearby St. Cecilia's in the Junction, that "our talking must be soft and light to accommodate ourselves to the intelligence of the women and children." 8 Scafuro's successor, Joseph Longo, wrote Archbishop McGuigan in 1936, that

\footnotetext{
${ }^{5}$ McEvay to Brick, 3 Aug. 1908, and Licking to McEvay, 12 Aug. 1908, McEvay Papers, AAT.

${ }^{6}$ Licking to McEvay, 12 Aug. 1908.

${ }^{7}$ Scafuro to McNeil, Scafuro Papers, 13 Jan. 1920, AAT. 1920, AAT.

${ }^{8}$ Scafuro to Treacy, 20 Jan. 1920.
} 
This parish [St. Clement's] may be rightly compared with [ sic] an african [with a lower case 'A'| Mission / with an upper case ' $M$ ']'; greediness, the war, the depression and communism made many Italians non $[$ sic $]$ only to $[$ sic $\mid$ forget their religious duties but to $\mid$ sic $]$ hate the priests... ${ }^{9}$

The Catholic archdiocese's treatment of Toronto's pre-war Italian immigrants cannot be ascribed only to a monolithic nature of the Church, but if there was one attitude that united hierarchy and parish clergy in a common front for dealing with the Italian immigrant problem in Toronto, it was that of a zealous missionary church "saving" an irreligious people. This frame of mind was almost identical to that of the Methodist home missionaries who somehow seemed always to be one step ahead of the Catholics in reaching out to the immigrants.

The Church of England Mission to the Italians which opened in November 1899 at 88 Edward Street in the heart of the Italian neighbourhood, was run by an ex-Roman Catholic priest from Calabria. In October 1905, the Methodists opened an Italian mission in the neighbourhood and within a few months took over the Edward Street site abandoned a few years previously by the Church of England. Rev. Giuseppe Merlino was placed in charge of the 45 regular members of the mission until 1908 when he was succeeded by Alfredo Taglialatela. In June 1907, a branch mission was inaugurated at the corner of Clinton Street and Mansfield Avenue in the Heart of the second Little Italy. Three years later it was replaced by the Claremont Street mission. In 1912 a store was purchased at the corner of Chandos Avenue and Dufferin Street for a mision for the third Little Italy. Preachers had been holding outdoor assemblies in that neighbourhood since 1910. The Catholic churches, then, were from three to six years behind the other two churches in establishing a presence in each of the Italian neighbourhoods. Although they were obviously not the only stimulus, the Italian Methodist missions were an additional incentive to establish Catholic parishes in the Italian neighbourhoods. ${ }^{10}$

\footnotetext{
${ }^{9}$ Longo to McGuigan, 13 April 1936, Longo Papers.

${ }^{10}$ Various letters, pamphlets, and reports on Italian Methodist Missions are available in the United Church Archives. See Italian Missions file, Annual Report of the Missionary Society Methodist Church, The Missionary Outlook, The Christian Guardian, Annual Report of the Home Department, all in UCA. More specifically, see The Italian Methodist House of Toronto, n.d., c. 1910, and "Dufferin Street United Chuch," ms., both in Toronto-Italian Church file, UCA. In Archives of the Anglican Diocese of Toronto, see Church of England, Mission to the Italians of Toronto \& Canada, First Annual Report 1899-1900 (Toronto, 1900).
} 
The backgrounds and personalities of individual priests more than a uniform church perspective accounted for the prevalence of a condescending attitude towards the immigrants. All of the pre-1934 Italian priests except two were Northern Italians and had studied in Italian seminaries between 1885 and 1915. They were therefore educated during an era in which Italian Catholics stressed the missionary role of the church, best exemplified in its programme to civilize and christianize the "savages" (Selvaggi) of Italy's African colonies. At the same time they were aware, and perhaps even shared in the northern Italian's condescending attitude towards the illiterate southerners. Social and geographical background, however, cannot explain totally the near disdain in which some of the Italian clergy in Toronto held their parishioners. At least three of the priests seem to have had serious problems in dealing with people, both laity and church hierarchy. Their personal shortcoming rather than ideological or regional differences were responsible for alienating parishioners and accentuating the tension between clergy and laity within the community. ${ }^{11}$

It was especially because of problems involving the clergy that Archbishop McEvay and his successors found the administration of Italians national parishes a tedious, time-consuming task. The most efficient method of dealing with the immigrants was to have a religious order with some experience in American ethnic parishes look after the Italian Catholics of the city. Certainly the serious problem of drawing Italian-speaking priests to the city might be solved that way. Until 1909, McEvay could depend on Father Pietro Pisani to provide priests. As an immigration specialist, Pisani had a good sense for locating and supplying clergymen for Italian parishes in North America. However, the turnover rate at Our Lady of Mount Carmel in its early years was high - three priests in just over four years. McEvay must also have understood that some of the clerics Pisani was supplying were outcasts from the old country. Joseph Longo had, after all, come to Toronto to create a fresh start after an orphanage scandal (of which he had been acquitted) in Turin, and rumours spread that Carlo Doglio, the first pastor at Mount Carmel in 1908, had a questionable relationship with at least one of the women who ostensibly served as his housekeeper. McEvay, after ordering Doglio to leave the Archdiocese, recommended him very strongly to the bishop of Rochester, New York. When Longo's

\footnotetext{
${ }^{11}$ See Joseph Longo, Aloysius Scafuro, and Our Lady of Mount Carmel Church Papers.
} 
past was discovered by the Toronto Archbishop and his secretary, the first reaction was to pass him off to some unsuspecting bishop elsewhere: "Pisani... also says he can get places for Italian Priests in the States but for some reason this priest does not want to go." 12 McEvay himself had entered the less than reliable network, and just as he was conveying questionable clergy to other dioceses, so could be except that more of the same was being deflected in his direction. If a religious order committed itself to a parish at least the replacements of pastors and assistants (resulting from a high turnover rate) would not be his responsibility.

The dearth of dependable clergy to look after the immigrants injected a spirit of competition among the North American bishops in their search for adequate priests. However, when the episcopal leaders turned for help to the religious orders they discovered an even more intense spirit of rivalry. The male religious orders serving Toronto's Italian immigrants before 1940 (as well as orders that tried to obtain parish work there) internalized the aggressive missionary programme of the Church as well as the imperialistic tendencies of the era. For the Redemptorists, Salesians, Dominicans, and Franciscans, expansionism was the key element in their attempts to acquire pastoral duties in the Italian churches. To meet this goal they vied for control of Toronto's Italian national parishes. When in 1907, Archbishop McEvay contacted the Redemptorist's superior in Baltimore regarding the possibility of Italian priests for the Toronto Archdiocese, he was dealing with a man who seven or eight years previously had embarked on a programme to expand missionary work in his order among North American immigrants. The movement was scotched by a shortage of personnel and in 1907, in a attempt to alleviate part of the problem and in response to McEvay's request, Licking asked superiors in Rome for a few professed Italian students. The Baltimore superior was unable to produce immediate

\footnotetext{
${ }^{12}$ McEvay to Hickey (Bishop of Rochester), 27 April and 13 May, 1910. McEvay to Apostolic Delegate, 5 Nov. 1909, Longo Papers. Doglio had been sent to Toronto by the Bishop of Buffalo in 1908; the bishop did not want his cleric back in 1910 . McEvay to Apostolic Delegate, 28 May 1910; Doglio to McEvay, 13 June 1910; Charles Colton (Bishop of Buffalo) to McEvay, 29 Oct. 1908. Pisani was aware of Longo's background when he recommended him to McEvay. In a 1908 article he devoted a page to discussing the plight of the poor cleric. See Pisani, "I problemi dell'emigrazione italiana," Rassegna Nazionale, part II, LXVI, fasc. CLXXXIV (April 1908), p. 516.
} 
results so that the following year, with the help of Pisani, McEvay obtained a secular priest, Carlo Diglio as Mt. Carmel's first pastor. ${ }^{13}$

Nevertheless, the Redemptorists did not abandon the effort and less than five years later they acquired control of Our Lady of Mount Carmel. Clearly, Father Arthur Coughlan, the first Redemptorist pastor of the parish, wanted to insure that his order's latest foothold in the Archdiocese should remain firm. Upon his arrival with his assistant, Dominic Viglianti at Mount Carmel, Coughlan made every attempt to have the archbishop notice the improvements the new team would make over the parish's previous pastor, Joseph Longo. Coughlan and Viglianti arrived on Palm Sunday, 1913, but did not attempt to deal with the general disorder of the church before the Archbishop's first visit one week later. "We did nothing in the church until yesterday, first of all because Father Longo did not ask us and secondly to let the Archbishop see for himself the filthy condition of the sacristy, etc." 14

Toronto's second national parish also passed from the control of secular to regular clergy in 1924, when the Salesian Fathers began a ten year term at St. Agnes Church. Until 1934 this order constantly queried the Archbishop about the possibility of taking on other Italian parishes in the city. Richard Sittini, the Salesian provincial in New Rochelle, New York, asked McNeil to begin looking for another order to run St. Agnes because McNeil had not responded to Sittini's plea to administer another parish in addition to St. Agnes. According to Salesian rules, two priests at their Toronto parish could not be considered a religious community he argued. Indeed the Salesians gave up Toronto's Italian parishes in 1934 for that very reason. In August 1931, Archbishop McNeil invited the Dominicans to administer St. Clement's parish. The provincial in Bologna, Italy, was enthusiastic in his response and in follow-up letters. He asked McNeil to stress to the Canadian province of the Dominicans how indispensable the Bologna province's help would be; otherwise the move to Toronto could not be justified. The

\footnotetext{
${ }^{13}$ Michael J. Curley, The Provincial Story: A History of the Baltimore Province of the Congregation of the Most Holy Redeemer, New York: The Redemptorist Fathers, Baltimore Province, 1963 , p. 252 . Also p. 431, fn. 126; Redemptorist Centenaries, p. 374 .

${ }^{14}$ Coughlan to Schneider, Schneider Papers, 17 March 1913, ABPR.
} 
negotiations were unsuccessful for the Dominicans because the Canadian provincial hesitated in giving permission for the Bologna province's entry. ${ }^{15}$

The religious order that eventually replaced the Salesian Fathers, the Franciscans of the Province of the Immaculate Conception (New York), were even more confident that they were bestowing a favour on Toronto's Italians when they sent their first confrères to Toronto in 1934. The provincial, Alfonso Parziale, mailed a statement of intent to expand parish work among the Italians, to Archbishop James McGuigan on 1 January 1935:

I would be a real blessing for the italian $[s i c]$ people, a great advantage to us, and a benefit to the diocese... I assure you that the Franciscans of the Immaculate Conception Province are ready and most willing to work for for $[s i c]$ the welfare of the Italian [sic] people, who are negligent, but still keep their faith; we wish to help them save their immortal souls.

Parziale hoped to impress the new Archbishop, James McGuigan, whom he assumed would continue his predecessor's policy of efficiency and expediency - when he noted that "With all the Italians under one direction, a system of mutual cooperation could be worked out with great advantage." The overture was successful and by the end of the year St. Clement's was under the control of the Franciscans. ${ }^{16}$

No sooner had matters been settled at St. Clement's than did the Franciscans attempt to complete their coup at controlling the Italian parish network of Toronto. The Redemptorists, who had not placed a confrère in Mount Carmel since 1927, even though they had a right to the church, intended to reinstall their own clergy in 1937. This was a cue for Parziale to send a memorandum to Archbishop McGuigan in June of that year. The letter combined the same old tactics that Franciscans and other religious orders had used previously to ingratiate

\footnotetext{
${ }^{15}$ Richard Sittini to Neil McNeil, 11 Aug. and 10 Dec. 1932, Salesian Papers, AAT. Brianza to Neil McNeil, 16 May 1932; see also same, 14 Aug. 1932, Dominican Papers, "Religious Orders - men outside diocese," AAT. See Also John Zucchi, "Italians in Toronto: Development of a National Identity, 1875-1935. Ph. D. Dissertation, University of Toronto, 1983, pp. 223-227.

${ }^{16}$ Alfonso Parziale to James McGuigan, 1 Jan. 1935, Franciscan Papers, "Religious Orders," AAT. Parziale to Procurator General of Franciscan Order, Rome, 20 June 1935, AFPIC. Also, there is a copy of the agreement in the Franciscan Papers, AAT.
} 
themselves with the city's Catholic hierarchy: criticism of predecessors ("If the Redemptorists are allowed to take over this parish the poor Italians will be worse off than they are under the present pastor"), missionary zeal ("We have taken over the care of the Italians of Toronto with all enthusiasm that we may get them back to the practice of their religion. Ours is a missionary work devoid of any material interest."'), the cult of efficiency ("The Franciscan Fathers already having the care of two of the Italian Parishes could work more satisfactorily and profitably if they had jurisdiction over all the Italians of Toronto"), and the astuteness to use cash as a last resort ("The proposition of Your Excellency to offer the Redemptorist Fathers some recompense is agreeaable to me. I think that the limit shall be $\$ 15,000$, however, I think that the sum of $\$ 10,000$, subject to modifications, should be enough."') ${ }^{17}$

The attitudes of hierarchy and clergy toward the Italian immigrants, and the eagerness with which religious orders sought new territories in Toronto's Italian parishes may give us the impression that these immigrants were mere pawns. The laity was never a docile group in any of the three Italian national parishes in Toronto. Laymen did not submit blindly to the whims of the Italian clergy. Harsh criticisms, insult, or any attempt by the clergy at over-extending its power in the community were challenged by tough resistance on the part of parishioners. From the earliest days of Mount Carmel Church, the Italians took an active role in parish organization and in voicing their opinions to the priest or archbishop. It is with this backdrop of lay initiative and interest in mind that we can understand the immigrants' reluctance to yield to the capriciousness of some of the priests.

In fact, the activism of the laity in Italian Catholic Toronto predated the establishment of Our Lady of Mount Carmel parish in 1908. The Glionna family had attempted earlier to purchase a Methodist church and to have it transformed into an Italian national parish. When, in June $1908, \mathrm{M}^{\mathrm{gr}}$ Sbarretti, the apostolic delegate, came to Toronto to attend the investiture of Fergus McEvay as Archbishop of the city (his predecessor, Dennis O'Connor, c.s.b. had just passed away), some Italians seized the opportunity to address the nunzio at St. Paul's Church where "they expressed their desire that some Italian priest might be particularly

\footnotetext{
${ }^{17}$ Parziale to McGuigan (Memorandum to His Excellency the Archbishop of Toronto), 21 June 1937, McGuigan Papers, AAT.
} 
appointed to look after their spiritual interests." 18 McEvay's solution was to have the Redemptorists allow the Italians use of the old St. Patrick's Church as its Irish parishioners were moving to larger premises nearby. However, he did not finalize his decision before being warned by the Redemptorist pastor of St. Patrick's Church, that he was treading dangerous waters:

I understand that the Italians have already expressed their opinion of this view to the effect that if the old church is not good enough for the Irish, it will not be good enough for the Italians. ${ }^{19}$

Eventually the Italians did find the building acceptable, but as their parish sprouted they directed their criticisms to other issues.

The first major problem in the parish involved the first pastor of Our Lady of Mount Carmel. Rev. Carlo Doglio claimed that the three women who lived with him at various times between 1908 and 1910 were his housekeeper, cousin, and sister. This may well have been true but the parishioners were suspicious. Archbishop McEvay enlightened the apostolic delegate about the refusal of the colony to put up with the scandal: "many Italians will not attend the church of account of these reports and other quarrels with some of the people."

Certainly the archbishop took the immigrants' criticisms very seriously. When he discovered in 1909 that his newly-arrived priest, Joseph Longo, had been involved in the above-mentioned orphanage scandal, he placed him elsewhere in the diocese: "I have enough troubles here among the Italians and the matter would be sure of falling into the paper." 20

Within the Italian national parishes criticism of the clergy did not subside in the post-World War I period. Unfortunately, most of our evidence is in the form of official correspondence, so that it is difficult to ascertain the true causes of intra-parochial conflicts. For example, in 1923, a great deal of bickering occurred in the St. Agnes Parish

\footnotetext{
${ }^{18}$ Sbarretti to McEvay, 3 July 1908 (No. 4569), McEvay Papers, AAT. Apparently the Glionna Family had made attempts earlier to purchase a Methodist chapel for Roman Catholic services for the Italian population.

${ }^{19}$ W.G. Licking to McEvay, 12 Aug. 1908, “Priests," McEvay Papers, AAT.

${ }^{20} \mathrm{~J}$. Kidd to Charles Doglio, n.d., 1909; McEvay to Apostolic Delegate, 28 May 1910, McEvay Papers, AAT. McEvay to Apostolic Delegate, 5 Nov. 1909, Longo Papers.
} 
Committee regarding the pastor's alleged missappropriation of funds. Some members resigned to give the pastor control of the parish until the archbishop returned from a trip. ${ }^{21}$ In the late 1920s the Parish Committee of Our Lady of Mount Carmel Parish filed a complaint in Italian with the archbishop regarding their pastor, Father Stephen Auad. Auad was a Syrian Maronite priest who had become a bi-ritualist after studying in Rome. The committee was highly critical of Auad: he was too busy to hear confessions; it was difficult to find him in the rectory or in the church; he rarely visited school children; his masses were too short, etc. The first objection was the main one - that Auad took little care of the Italians and rather depended on the "Inglesi" (the English) of the parish. The immigrants wanted a pastor of their own national background, a cleric who was more responsive to their needs. ${ }^{22}$

Lay participation of course was not defined solely by criticism of the clergy. The national parish was the focus of many activities which can be divided into two main spheres - the religious and devotional on the one side and the social and patriotic on the other. The distinction is important for an understanding of social organization within the community. The clergy had prestige among Toronto's Italian immigrants because it provided for their spiritual and ritualistic needs; however, it was never the central power within the ethnic group and indeed its power was subordinate to that of the elite of bankers, wholesale grocers, steamship agents, and later, the Fascist club directors.

Unfortunately, few documents have survived which can catalogue the extend of religious and devotional life within the early Italian parishes of Toronto. The impression one has from reading the correspondence of priests, pastoral visitations, and newspaper accounts, is that a relatively small part of the Italian Catholic population attended Mass regularly; those who did practice their faith were active at the various church functions. There is little statistical evidence to prove this and the impressionistic statements of various priests of the subject may very well have been biased.

\footnotetext{
${ }^{21}$ Unsigned letter by pastor of St. Agnes Church (Fr. Basso), "Egregi Signori del Comitato e Cari Parochiani di S. Agnese," ("To Parish Committee and Parishioners"), n.d.; "Cara Popolazione di S. Agnese ("Dear People of St. Agnes"), no signature, n.d.; letters of resignation of F. A. Miceli, A. Frediani, Valentino Federico, and A. Teolis, 21 March 1923, Salesian Papers, "Religious Orders," AAT.

${ }^{22}$ Our Lady of Mount Carmel Parish Committee to McNeil, n.d. (c. 1903) (my translation), Stephen Auad Papers, AAT.
} 
Although the city's Italian immigrants had a low rate of church attendance they participated in parish activities and especially in events involving their hometown churches in Italy. One of the best indicators of parish activity is the pastoral visitation, the report of the bishop's visit and examination of the parish. The earliest surviving visitations for the three Italian national parishes are for 1948; there is no evidence of earlier visitations. However, since virtually no new Italian immigrants had arrived in Toronto during and immediately after World War II, the 1948 visitations help describe the religious practices and associational life of pre-war Italians in Toronto. Parish associations included the Holy Name Society, Catholic Women's League, Sodality of the Blessed Virgin Mary, the Catholic Youth Organization, the Saint Vincent de Paul and other societies. Membership at Mount Carmel for all these associations totalled 395. St. Agnes Parish, with a population of about 5000 had 320 active members in these societies. St. mary of the Angels (St. Clement's) with a population of 2,500, claimed about 426 members in its parish organizations, or 15 to 20 per cent of the parish. The proportion of active members is rather high considering that the DufferinDavenport Little Italy had many young families with children who could not hold memberships; that many parishioners were active in the Fratellanza and Famee Furlane Mutual benefit societies; and that most of the men who worked long hours in construction, and their older daughters, and some wives who worked in the needle trades downtown arrived home fatigued in the early evening.

The associations listed in the pastoral visitation were established North American parochial organizations, many of which did not exist in the small Italian agrotowns from which most of Toronto's immigrants came. It is understandable that membership would not have been very high because these clubs required acculturation on the part of the immigrant: they were not authentic forms of old-world religious practice. The few recorded accounts that have survived describing participation of Toronto's immigrants in their old -world hometown parish events usually fundraising drives - suggest that these "urban villagers" were indeed very active in their "other" or former parishes, even though they lived in Toronto. A number of reasons probably dictated the choice to donate to the hometown's fund-raising drives: genuine generosity, village traditions which prescribes that money be sent back to the village by those whom its pastor might still consider his parishioners; or one's ascriptive status among one's village group in Toronto. In other words, one was expected to give for reasons of sub-ethnic reputation and honour. Not to do so was to ostracize oneself from the townsgroup in Toronto. 
A number of townsgroups in the city delegated one person to collect money from fellow townsmen and to send it back to their hometown for the celebration of the town patron saint's feast day. In the 1930s, one woman was responsible for the collection among the immigrants from Villa St. Lucia, Frosinone, in Toronto, for the feastday of Madonna delle Grazie (Madonna of the Graces). Another man did the same for his townsmen from Montorio dei Frentani, Campobasso, for their San Rocco (St. Roch) celebrations. In 1931, Michele Pucacco, who normally canvassed Toronto's families from Casacalenda, Compobasso, for the Maria S.S. della Difesa celebrations, "knowing the actual conditions of his townspeople [in Toronto because of the Great Depression] abstained from doing so, and was content with sending fifty lire back to Italy.' In June 1931, Salvatore Domenico Graziadei began a fund-raising drive for construction of the new San Rocco church in his hometown, Pisticci (Matera). He exhorted his townsmen in Toronto to be

generous with their offering. That which we give is for a good cause; we are giving to Pisticci, to our protector [patron saint], towards beautifying our hometown, because the planned church will be a work of art.

Vito Cammisa and Antonio Iannuzziello were in charge of collecting funds, and by November had collected over $\$ 120.00$ from 135 pisticcesi. ${ }^{23}$

Some of the townsgroups were able to insert their hometown celebrations into the activities of the Italian national parishes. Indeed, Mount Carmel internalized two such feasts to the point of making them important annual events for the entire Italian population. For years, the immigrants from Termini Imerese, in Sicily, assembled the Good Friday Passion Play in vivid - one could even say gory - detail. Another hometown tradition continued by the termitani was the weekly Tuesday afternoon devotions to St. Anthony. Other Italians also attended but the largest group was composed of women from Termini Imerese. For these women dispersed throughout the city in fruit stores, the

\footnotetext{
${ }^{23}$ Progresso Italo-Canadese, "Per la festa di Villa S. Lucia" 11 June 1931, p. 3; "Sottoscrizione per la festa di S. Rocco," 27 Aug. 1931, p. 3; "Un bel gesto," 17 Sept. 1931, p. 3; "Zelante Michele Pucacco," 25 Sept 1930, p. 3; Progresso Italo-Canadese, "Ai Pisticcesi $[$ sic $]$ di Toronto," 18 June 1931, p. 3; "Sottocrizioni pro chiesa," 17 Sept. 1931, p. 3.
} 
devotions provided an opportunity to keep in contact with one another. The annual feastday of Our Lady of Mount Carmel would most certainly have been celebrated by various townsgroups in Toronto because she was the patron saint of numerous Italian towns. St. Agnes Church, too, began observing the feastday in 1930 .

Next to the Good Friday Passion Play, the most important feastday in the community was that of San Rocco, the patron saint of two of the most prominent towns represented in Toronto, Monteleone di Puglia and Modugno di Bari. In Italy the feast traditionally celebrates the harvest which in Monteleone coincides with the period of the feastday, August 16. However, Modugno, being at a higher altitude, had a later harvest and therefore observed the holy day two weeks later. Months of negotiations with the archbishop won them the concession to hold a solemn procession in late August. In the 1950s the archbishop was approached once again because of a controversy over which group of townspeople - the monteleonesi or the modugnesi - owned the San Rocco statue that was carried in the procession. It took five years for the archbishop to find a happy solution to the small crisis which for years had kept the two townsgroups segregated across the aisle from each other at M. Carmel's Sunday services. ${ }^{24}$

Within the religious life, then, Italian immigrants were able to live on two levels. On the whole they rejected Italian Protestantism but they were not prepared to accept Irish Catholicism. Those who did observe church laws were open to the Italian national parish structure organized by the Italian clergy through the Canadian hierarchy, but they often defined the limits of acceptable behaviour for priests. The immigrants demanded lay participation in the parish and resisted overbearing or uncaring priests, or priests who gave scandal. They also adapted to the national parish structures by merging their hometown celebrations with those of their parish, and by providing financially for the feasts and churches of their hometowns, as well as for religious celebrations of parishes in Italian Toronto. In that sense Toronto's Italian immigrants had come a long way since 1908. At the opening of Mount Carmel parish in that year, Father Casassa of St. Anthony's Italian Parish in Buffalo had preached the sermon at the inauguration ceremonies. Aware of the fragile bonds of a consolidating community, Casassa stressed the

\footnotetext{
${ }^{24}$ On the problems between the monteleonesi and modugnesi see Our Lady of Mount Carmel Papers, AAT.
} 
ideal of "Christian citizenship": "Now that they had their own church," said the priest, "they would join in attendance and activities, they would unite with ther compatriots and bury all Old Country prejudices of locality or politics, in working side by side as good Catholics in the new land of their adoption." ${ }^{25}$ By 1935, the Italian immigrants in the city lived in both worlds for they could identify with an Italian national parish in the city and also with one of the hometown groups which comprised the three Italian parishes in Toronto.

At the same time, we must keep in mind that many Italians broke away from the Church or remained neutral to it. Between four and nine per cent of the population joined methodist or evangelical missions. Many simply stayed away from the churches. The Irish stamp on Toronto's Catholic churches or even the pan-Italian nature of the national parishes had little meaning for these village people who had been brought up in their own respective hometowns' particular cults.

In many ways the Toronto Archdiocese had been insensitive to the immigrants' upbringing. On the one hand we can argue that the Toronto hierarchy could not be expected to perceive these particular details of the migrant's experience and background. On the other hand, the archbishops found it easier to appoint specialists, priests, and later, religious orders, to resolve the problems of the immigrants. They also found it more expedient to view Italians as an homogeneous group with one cult. In fact, the approach may have done more harm than good in the long run in that the Archbishop never did become personally involved with the difficulties and problems, both conceptual and emotional, of immigrant Catholics from Italy. Thus a main Catholic Church developed in the city, Irish in character; an annex Church developed for immigrants. The immigrants were never integrated into the maintream church and still have not been integrated in the post-war period. They are still regarded as peripheral members of the body who can be taken care of with the appointment of special delegates. It will take time to heal the damage begun three generations ago.

25 “'Inauguration of Italian Parish," Catholic Register, 12 Nov. 1908, p. 1. 